\title{
Effect of accounting for public holidays on skills of atmospheric composition model SILAM v.5.7
}

Yalda Fatahi, Rostislav Kouznetsov, Mikhail Sofiev

Finnish Meteorological Institute, Helsinki, 00560, Finland

5 Correspondence to: Yalda Fatahi (yalda.fatahi@fmi.fi)

\begin{abstract}
Changes in anthropogenic activity during public holidays influence air pollutant concentrations. The objective of this study is to quantify the public holiday's effect on air quality and to analyse the added value of accounting for the holidays in AQ modelling and forecasting. Spatial and temporal distributions of atmospheric concentrations of the major air pollutants ( $\mathrm{PM}_{2.5}, \mathrm{PM}_{10}, \mathrm{SO}_{2}, \mathrm{CO}$,

$10 \mathrm{NO}_{2}, \mathrm{NO}_{x}$, and $\mathrm{O}_{3}$ ) were considered at the European scale for all public holidays of 2018. Particular attention was given to the events with the most-pronounced continental or regional impact: Christmas and New Year, Easter, May vacations and last days of Ramadan. The simulations were performed with the Eulerian chemistry transport model SILAM v.5.7. Three model runs were performed: the baseline with no treatment of holidays, the run considering holidays as Sundays, and the run forcing $80 \%$

15 reduction of emissions during holidays, for the week-day sensitive sectors. The emission scaling was applied on a country basis. The model predictions were compared with in-situ observations collected by the European Environment Agency. The experiment showed that even conservative treatment of official holidays has a large positive impact on NOx (up to $30 \%$ of bias reduction in the holiday days) and also improves the $\mathrm{CO}, \mathrm{PM}_{2.5}$ and $\mathrm{O}_{3}$ predictions. In many cases, the sensitivity study suggested deeper

20 emission reduction than the level of Sundays. An individual consideration of the holiday events in different countries may further improve their representation in the models: specific diurnal pattern of emissions, additional emission due to fireworks, different driving patterns, etc.
\end{abstract}

Keywords: holiday emissions of air pollutants, AQ modelling, SILAM model, AQ model sensitivity

\section{1. Introduction}

Air quality (AQ) and its temporal and spatial changes are determined by human activities via the release of various aerosols and gases (Derwent and Hjellbrekke, 2012; Fu et al., 2020; Hassan et al., 2013; Karl et al., 2019; Kukkonen et al., 2020; Lehtomäki et al., 2018; Shi et al., 2019), and modulated by meteorological conditions (Jacob and Winner, 2009; Jhun et al., 2015; Singh et al., 2013; Sofiev et al., 30 2020).

The ability of atmospheric composition models to follow the temporal variability of air pollution critically depends on representation of the emission temporal behavior by the inventories used by the models. Arguably the most-difficult task is to catch the variations originating from rare events. Changes 
in the human behavior during non-working days of various type (Beirle et al., 2003; de Foy et al., 2020,

35 2016; Elansky, 2020; Gour et al., 2013; Hassan et al., 2013; Xu et al., 2017; Zou et al., 2019; Rozbicka and Rozbicki, 2016), including some religious ceremonies (Dasari et al., 2020), cultural practices (Khezri et al., 2015; Nodehi et al., 2018; Ye et al., 2016), celebratory events and festivities (Hoyos et al., 2020; Jiang et al., 2015; Lai and Brimblecombe, 2017; Retama et al., 2019), etc cause large variations of emission of air pollutants, which are hard to quantify because of their specificity.

40 However, the weekend and (some) holiday effects have certain similarities, which might allow drawing an analogy between weekday vs. weekend and holiday vs. non-holiday pollution levels.

Majority of currently available emission inventories are built as gridded yearly or monthly totals for the key primary pollutants (Frost et al., 2013; Granier et al., 2019, 2011), (https://eccad.aeris-data.frl, access 5.2.2021). Temporal variations at shorter time scales received less attention but their impact on AQ

45 itself and the model's ability to reproduce the concentration has been considered in several studies as well (Fu et al., 2013; Gioli et al., 2015; Guevara et al., 2017, 2021; Iriti et al., 2020; McGraw et al., 2010). Several studies have demonstrated the crucial role of spatial and temporal resolution of emission inventories in environmental science, air quality modeling, and air pollution policy making (Frost et al., 2013; Gioli et al., 2015; Zhao et al., 2015; Zhou et al., 2020).

50 A number of observations-based studies focused on effects of the weekends and, sometimes, specific holidays on pollutants concentrations (Chen et al., 2019; Forster and Solomon, 2003). Lonati et al. (2006) examined the weekend effect for particulate matter $\left(\mathrm{PM}_{10}\right.$ and $\left.\mathrm{PM}_{2.5}\right)$ emissions from traffic sources in the city of Milano. The research indicated that concentrations of these compounds in the urban area were lower than the levels during the weekdays. Gour et al. (2013) considered differences in

55 the pollution levels during weekends and weekdays in Delhi and showed that pollution variation follows the pattern of working activities on weekends and weekdays. Parra and Franco (2016), pointed out that the concentration of $\mathrm{NO}_{2}, \mathrm{NO}_{x}, \mathrm{CO}$, and $\mathrm{PM}_{2.5}$ in working days is higher than that at the weekend, but the concentration of $\mathrm{O}_{3}$ in working days is lower than that of the weekend, due to ozone titration. In (2017), Ding et al. reported that during the Chinese New Year the NOx emissions are usually lower by 60 about 10\% reflecting the lower business and industrial activities.. In a recent study, Hua et al. (2021) estimated the holiday effect of $\mathrm{PM}_{2.5}$ and $\mathrm{NO}_{2}$ by a Generalized Additive Model (GAM) with regard to time and meteorological parameters at 34 air quality monitoring stations during the five heating seasons from 2014 to 2019 in Beijing. According to their results, the holiday effect was much stronger than the weekend effects with increasing $\mathrm{PM}_{2.5}$ by $2 \%$ to $30 \%$ and decreasing $\mathrm{NO}_{2}$ in contrast.

65 Khalil et al. (2016) analysed hourly measurements of nitrogen oxide (NOx), non-methane hydrocarbons (NMHCs), ozone $\left(\mathrm{O}_{3}\right)$, sulphur dioxide $\left(\mathrm{SO}_{2}\right), \mathrm{PM}_{2.5}$, and $\mathrm{PM}_{10}$ collected at the coastal town of Yanbu, Saudi Arabia during weekends, Eids, Ramadan, and the Hajj periods and demonstrated that the ozone concentrations stay practically the same over these holiday days but the precursor levels are 
significantly lower. They reported a substantial increase in night-time emissions during Ramadhan due

to the reversal of diurnal activities (day to night).

The fireworks and bonfires during Christmas and New Year of 2013 and 2014 were recognized as the main sources of $\mathrm{PM}_{2.5}$ in Mexico city by Retama et al. (2019). Singh et al. (2019) considered the effect of fireworks on air quality, visibility, and human health and reported significant changes in pollutant concentrations and a decrease in visibility. Yao et al. (2019) studied air quality trends and fireworks

75 impact in Shanghai during spring festivals from 2013 to 2017 by monitoring hourly $\mathrm{PM}_{2.5}$ and gaseous pollutants at an urban and a suburban sites. A decreasing trend of $\mathrm{PM}_{2.5}$ in this study revealed the positive effect of firework regulation on air quality.

Recently, various methods based on observed data and models were applied to measure the impact of COVID-19 lockdown on air pollution. These studies investigated the role of transport and industry

80 sectors (as the main sources of air pollution) on pollutants concentrations during the lockdown (Fan et al., 2020; Grivas et al., 2020; Huang et al., 2020; Menut et al., 2020; Sharma et al., 2020; Wang and Su, 2020).

The above works showed that the effects of isolated events, such as public holidays, can be substantial. Yet its systematic analysis at large scales (e.g., a continent and a full year) is missing and a systematic

85 approach to their incorporation into AQ models is yet to be developed.

The goal of the current paper is to address this gap and to make the first step towards incorporation of the public holidays into the regular atmospheric composition and air quality modelling in Europe. We quantified the added value of a comparatively primitive and conservative inclusion of official holidays into temporal profiles of emission of air pollutants. Secondly, a sensitivity study was performed

90 demonstrating the extent of the necessary adjustments and potential benefits of a more detailed analysis of each specific holiday event.

The paper is organised as follows. The next section presents the methodology of the study: information on the European holidays, ways of their incorporation in the emission temporal profiles, the atmospheric composition model SILAM v.5.7 and its setup, as well as the statistical measures of the

95 model performance. The Results section presents the outcome of the annual SILAM computations for 2018 and the impact of the holiday information on the model skills. The Discussion section compares the outcome with other studies and demonstrates the sensitivity of the results to the changes in the holiday emission representation.

\section{Materials and methods}

\subsection{European Holidays}

We collected a list of official holidays in Europe from the Calendarific global holidays API (https://calendarific.com/api-documentation?v=2, access 10.01.2021) for the full year of 2018. We 
consider the events marked with "National holiday", "Local holiday" or "Common local holiday" as holidays (see examples for some European countries in Table 1 - Table 3).

105 The model computations included all holidays in 2018 but, for the sake of brevity, the analysis below will concentrate on the Christmas and New Year weeks, Easter (analysed at the European scale), and the Festival of Breaking the Feast at last days of Ramadan (Eid al-Fitr, analysed for Turkey).

Table 1. Official holidays, example of Finland, 2018.

\begin{tabular}{|l|l|l|l|l|l|}
\hline 1 Jan & New Years' Day & 10 May & Ascension Day & 24 Dec & $\begin{array}{l}\text { Christmas } \\
\text { Eve }\end{array}$ \\
\hline 6 Jan & Epiphany & 22 Jun & Midsummer Eve & 25 Dec & $\begin{array}{l}\text { Christmas } \\
\text { Day }\end{array}$ \\
\hline 30 Mar & Good Friday & 23 Jun & Midsummer & 26 Dec & Boxing Day \\
\hline 2 Apr & Easter Monday & 3 Nov & All Saints' Day & & \\
\hline 1 May & May day & 6 Dec & Independence Day & & \\
\hline
\end{tabular}

Table 2. Official holidays, example of Germany, 2018.

\begin{tabular}{|c|c|c|c|c|c|}
\hline 1 Jan & New Years' Day & 10 May & Ascension Day & $26 \mathrm{Dec}$ & Boxing Day \\
\hline $30 \mathrm{Mar}$ & Good Friday & 21 May & Whit Monday & & \\
\hline $2 \mathrm{Apr}$ & Easter Monday & $3 \mathrm{Oct}$ & $\begin{array}{l}\text { Day of German } \\
\text { Unity }\end{array}$ & & \\
\hline 1 May & May day & $25 \mathrm{Dec}$ & Christmas Day & & \\
\hline
\end{tabular}

110

Table 3. Official holidays, example of Turkey, 2018.

\begin{tabular}{|c|c|c|c|}
\hline $1 \mathrm{Jan}$ & New Year's Day & $15 \mathrm{Jul}$ & $\begin{array}{l}\text { Democracy and National } \\
\text { Unity Day }\end{array}$ \\
\hline $23 \mathrm{Apr}$ & $\begin{array}{l}\text { National Sovereignty and } \\
\text { Children's Day }\end{array}$ & 21 Aug & Sacrifice Feast \\
\hline 1 May & Labor and Solidarity Day & 22 Aug & Sacrifice Feast Day 2 \\
\hline 19 May & $\begin{array}{l}\text { Commemoration of Atatürk, } \\
\text { Youth and Sports Day }\end{array}$ & 23 Aug & Sacrifice Feast Day 3 \\
\hline 15 Jun & Ramadan Feast & $24 \mathrm{Aug}$ & Sacrifice Feast Day 4 \\
\hline 16 Jun & Ramadan Feast Day 2 & 30 Aug & Victory Day \\
\hline 17 Jun & Ramadan Feast Day 3 & 29 Oct & Republic Day \\
\hline
\end{tabular}




\subsection{Atmospheric composition model SILAM}

SILAM (System for Integrated modeLling of Atmospheric coMposition, http://silam.fmi.fi/, access: 17.01.2021) is an offline 3D chemical transport model (Sofiev et al., 2015a), also used for emergency

115 decision support (Sofiev et al., 2006) and inverse atmospheric composition problems (Sofiev, 2019; Vira and Sofiev, 2012). The model incorporates Eulerian and Lagrangian dispersion frameworks and a variety of chemical / physical transformation modules covering the troposphere and the stratosphere (Carslaw et al., 1995; Damski et al., 2007; Gery et al., 1989; Kouznetsov and Sofiev, 2012; Sofiev, 2002, 2000; Sofiev et al., 2010; Yarwood et al., 2005). SILAM features a mass-conservative positivedefinite advection scheme based on principles laid down by M.Galperin (Galperin et al., 1996). The model can be run at a range of resolutions and coverage starting from a kilometre scale over a limited area and up to the whole globe (Brasseur et al., 2019; Kouznetsov et al., 2020; Petersen et al., 2019; Sofiev et al., 2020, 2015b; Xian et al., 2019). The vertical structure of the modelling domain consists of stacked layers starting from the surface. The layers can be defined either in z- or hybrid sigma-pressure coordinates. The model can be driven with a variety of numerical weather prediction or climate models.

\subsection{Simulation setup}

The simulations were performed for the whole year of 2018 for the European domain with the setup following the operational configuration of SILAM in the Copernicus Atmospheric Monitoring Service (CAMS) regional air quality forecasts, as of November 2020 (https://atmosphere.copernicus.eu, access 130 20.02.2021). The only exception was a twice coarser grid resolution to reduce the computational costs (Table 4).

Table 4. SILAM setup.

\begin{tabular}{|l|l|}
\hline Domain and resolution & $25 \mathrm{~W}-45 \mathrm{E}, 30 \mathrm{~N}-72 \mathrm{~N}, 350 \times 210$ cells of $0.2^{\circ} \times 0.2^{\circ}$ size \\
\hline Vertical structure & $\begin{array}{l}10 \text { stacked layers with upper boundaries at 25, 75, 175, 375, 775, } \\
1500,2700,4700,6700 \text { and } 8700 \mathrm{~m} \text { above surface }\end{array}$ \\
\hline Boundary conditions & $\begin{array}{l}\text { First-day operational C-IFS (Integrated Forecasting System of } \\
\text { European Centre for Medium-Range Weather Forecasting ECMWF } \\
\text { with online-coupled chemistry) forecasts at } 0.4^{\circ} \text { resolution }\end{array}$ \\
\hline Meteorological driver & $\begin{array}{l}\text { First-day operational IFS forecasts interpolated to } 0.1^{\circ} \times 0.1^{\circ} \text { regular } \\
\text { lon-lat grid }\end{array}$ \\
\hline $\begin{array}{l}\text { Anthropogenic } \\
\text { emissions }\end{array}$ & $\begin{array}{l}\text { CAMS_REG_AP v4.2/2017 with GNFR temporal and vertical } \\
\text { profiles (https://eccad.aeris-data.fr/, access 5.2.2021) }\end{array}$ \\
\hline Natural emissions & $\begin{array}{l}\text { SILAM sea-salt (Sofiev et al., 2011), dynamic biogenic emissions } \\
\text { based upon Poupkou et al. (2010), mineral dust }\end{array}$ \\
\hline
\end{tabular}




\begin{tabular}{l|l}
$\begin{array}{l}\text { Chemical and aerosol } \\
\text { transformations }\end{array}$ & $\begin{array}{l}\text { Modified } \mathrm{CBM}-5 \text { gas-phase transformation, } \mathrm{SO}_{4}, \mathrm{NO}_{3}, \mathrm{NH}_{4} \text { ion } \\
\text { chemistry, } \mathrm{SO}_{2} \text { oxidation, nitrate formation, Volatility-basis set for } \\
\text { secondary organics }\end{array}$ \\
\hline $\begin{array}{l}\text { Deposition } \\
\text { Dry: Resistance approach (Wesely, 1989) for gases, (Kouznetsov and } \\
\text { Sofiev, 2012) for aerosols, Wet: SILAM v2018 wet deposition } \\
\text { scheme }\end{array}$
\end{tabular}

The anthropogenic emissions in CAMS_REG_AP v4.2 inventory are given as maps of annual totals separately for each country and seven GNFR sectors (European Environment Agency., 2013). To get the hourly emissions, the annual means are scaled with three temporal profiles, defined separately for each sector, corresponding to month-of-year (MOY), day-of-week (DOW), and hour-of-day (HOD) profiles (Granier et al., 2019). In the CAMS-regional operational setup, the anthropogenic emissions are used without accounting for public holidays.

140 To assess the sensitivity of air concentrations of pollutants to holidays, three SILAM runs were made: the baseline (hereinafter, the BL case), with the holiday days considered as Sundays (the HS case), asensitivity run with holidays getting $80 \%$ of emission reduction for the sectors affected by the DOW profile (the R3 case, considered in the Discussion section). Technically, the emissions were adjusted by altering the DOW scaling coefficients for dates and countries where the holidays occur. For the HS case

145 the coefficients were set to their Sunday values, and for the R3 case they were forced to $0.2 \times$ of the weekday value. The DOW coefficients for the affected sectors are shown in Figure 1. Other sectors (D_Fugitives, G_Shipping, H_Aviation, I_OffRoad, J_Waste, K_AgriculturalLivestock, and L_AgriculturalOther) have unity DOW coefficients for all three cases.

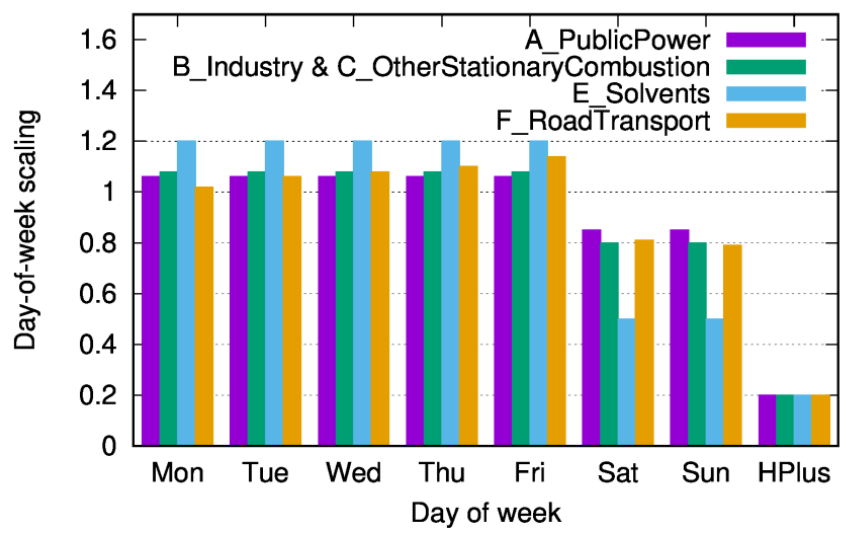

Figure 1. Day-of-week coefficients for the affected sectors. HPlus is the value forced for national holidays for the R3 case. 


\section{3. Evaluation scores}

For evaluation of the simulations we used the hourly data of the AQ monitoring stations downloaded from the European Environmental Agency portal (EEA, http://discomap.eea.europa.eu/map/fme/AirQualityExport.htm, visited 10.01.2021). Since we focus on regional-scale effects, a subset of representative stations was selected, namely, the stations classified

155 from 1 to 7 according to Joly and Peuch (2012) classification. This dataset is also used for the operational CAMS-regional evaluation (751 stations over the European domain).

The effect of holidays was considered for the main pollutants observed by the EEA network: PM 2.5 , $\mathrm{PM}_{10}, \mathrm{SO}_{2}, \mathrm{CO}, \mathrm{NO}_{2}, \mathrm{NO}_{\mathrm{x}}$, and $\mathrm{O}_{3}$. Five statistics were considered following the CAMS evaluation standards: bias, fractional bias (FracB), Pearson correlation coefficient (corr), RMSE, and fractional gross error (FGerr).

We considered the effect of holidays at two temporal scales. The short-term impact was analysed for the one-week period centred around each holiday day. For each day of this period, the spatial statistics were computed across the observational stations, and evolution of these statistics from day to day was compared between the SILAM runs. The long-term longitudinal effect was analysed at annual level for the whole 2018 and attention was given to the temporal statistics computed for the stations time series. Since the diurnal profile of emission during holidays is unknown, albeit probably specific for each event and country, the current study mainly used daily averaging of both observational and model data for computations of the statistics.

\section{Results}

\subsection{Short-term impact of public holidays}

The impact of holidays on the SILAM spatial skills was the largest for the Christmas week (Figure 2a). As expected, the Christmas period is characterised by lower emissions, which resulted in a high bias of the BL model run and almost 50\% growth of the RMSE compared to surrounding days. The reduction of emission in the HS run improved the performance but did not eliminate the problem completely.

175 Comparison of daily-mean concentrations showed reduction of the model bias for the HS run by $\sim 4.5$ $\mu \mathrm{g} \mathrm{m}{ }^{-3}$ of $\mathrm{NO}_{2}$. Consequently, the RMSE was also lower, by $\sim 14 \mu \mathrm{g} \mathrm{m}^{-3}$. These improvements constitute about $26 \%$ of the baseline statistics (see Figs. S1-S6 in the Supplementary section for other species). Examples of the time series of the modelled and observed $\mathrm{NO}_{2}$ concentrations at individual stations (Figure 2b, c) show that the HS run, being a step in the right direction, incorporated only a fraction of the actual emission reduction. 
(a)

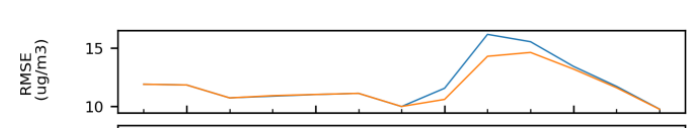

客

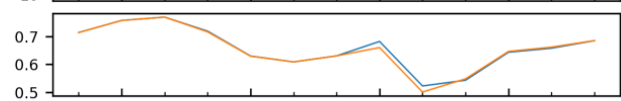

:

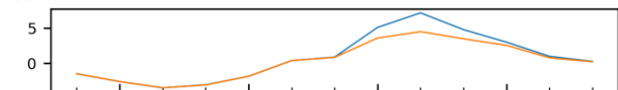

$\underset{\substack{0 \\ \mathbb{4}}}{\mathbb{0}}$

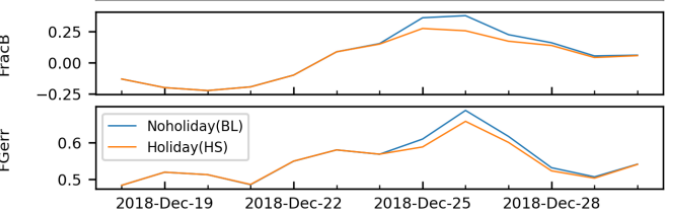

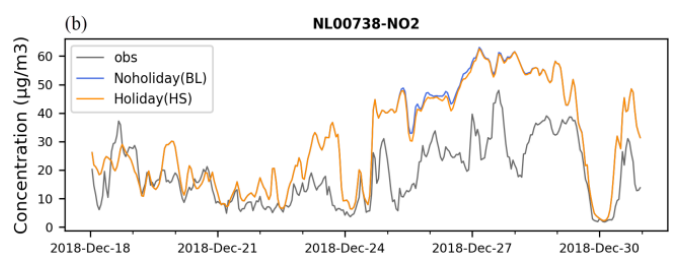

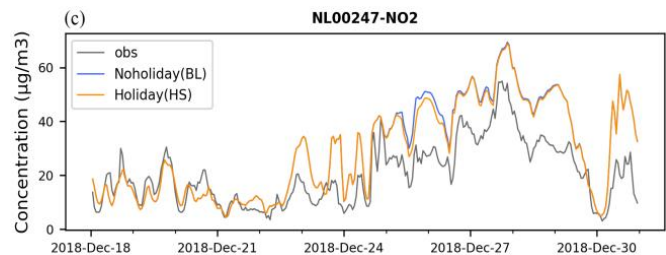

Figure 2. (a): SILAM daily-mean spatial scores for Christmas (whole Europe), (b, c): Time series of the modelled and observed concentrations for two stations in the Netherlands.

The New Year holidays have substantial impact on the first two days in January (Figure 3a). The HS

run showed $\sim 10 \%$ lower RMSE and about $1 \mu \mathrm{g} \mathrm{m}^{-3}$ reduction of bias. However, similar to the Christmas case, the Sunday emission level may be a too conservative reduction for this event, which is well visible in Figure 3b, c.

Comparing the HS and BL runs for Easter (Figure 4), one can see a substantial improvement of the scores for the days of the event. Similarly to the winter holiday week, Easter emission reduction seems

190 to be deeper than that of Sundays (see results for other species in the Supplementary Materials, Figs. S7- S12).

(a)

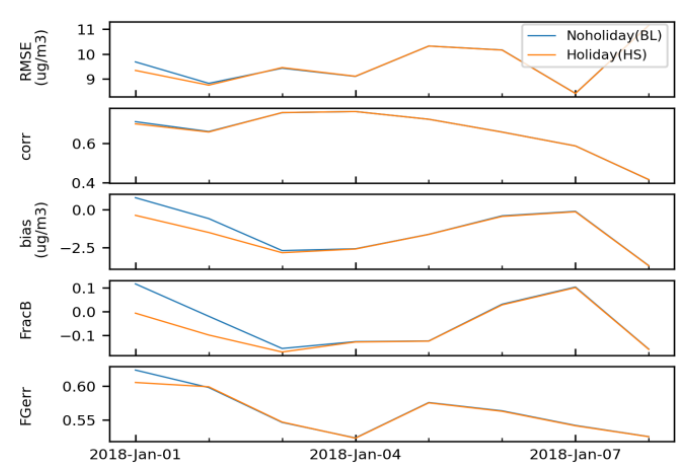

Opstations_SpatialStats_NO2
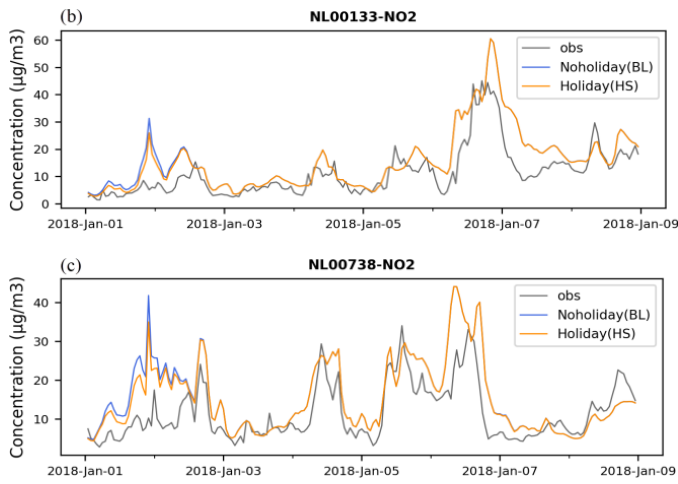

Figure 3. (a): SILAM daily-mean spatial scores for New Year holiday (whole Europe), (b, c): Time series of the modelled and observed concentrations for two stations in the Netherlands. 
(a)
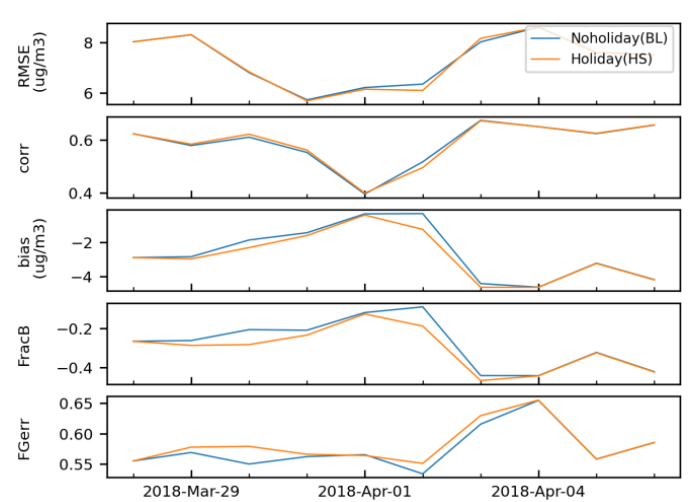
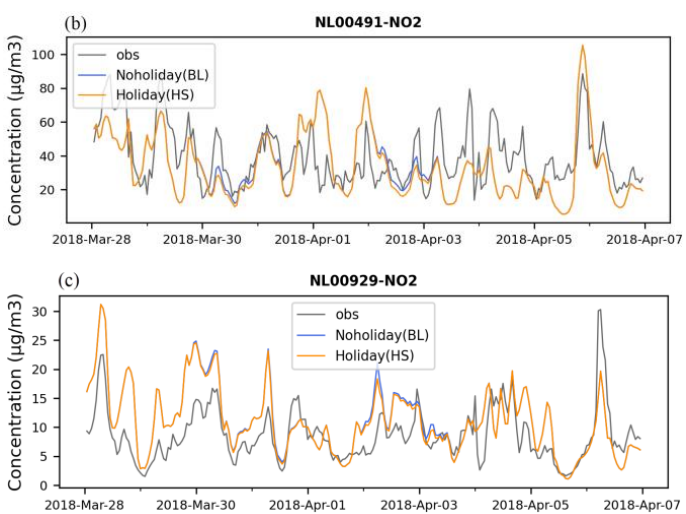

Figure 4. (a): SILAM daily-mean spatial scores for Easter (whole Europe), (b, c): Time series of the modelled and observed concentrations for two stations in the Netherlands.

The first 10 days of May were considered as an example of late-spring / summer vacations (there are no whole-Europe holidays during summer itself). The HS run showed slightly lower values for RMSE but, similar to Easter, initially negative bias increased further. Nevertheless, the bias time series became smoother comparing to the $\mathrm{BL}$ one, which is an indication of improvement: the systematic emission under-estimation should be handled separately. Reduction of NOx resulted in a substantial improvement of the ozone scores (Supplementary Material, Figs. S13- S18). This connection was the strongest among all holidays throughout the year, owing to the active chemistry and photolysis in May.

(a)
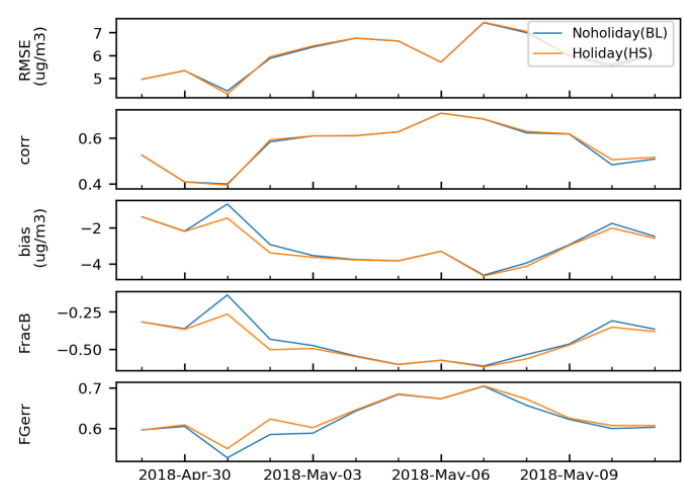
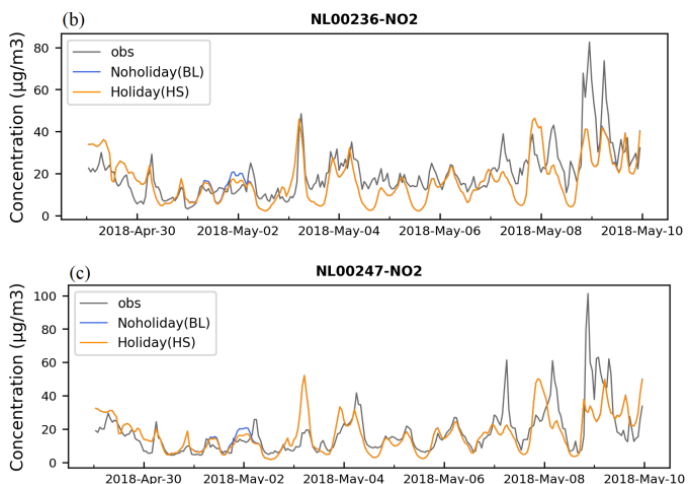

Figure 5. (a): SILAM daily-mean spatial scores for May vacations (whole Europe), (b, c): Time series of the modelled and observed concentrations for two stations in the Netherlands. 
205 In the Muslim countries (Turkey, Albania), the Ramadan month is not a public holiday as a whole, just working hours are reduced, which is not reflected in the HS run. Only the last three days of Ramadan the Ramadan Feast - are the public holidays in Turkey (Table 3, Figure 6 for $\mathrm{NO}_{2}$, Supplementary material for other species, Figs. S19- S24). For these days, there are distinct differences between the BL and HS model runs. However, similar to Easter and the May day, the model is generally low biased for

$210 \mathrm{NO}_{2}$ in Turkey during this period, therefore the additional reduction of the concentrations is, formally speaking, not an improvement: the negative bias increases. Nevertheless, it is a step in the right direction, as seen from the reduced variations of the model skills of the HS run: handling a flat systematic bias is easier than a scatter. The $\mathrm{NO}_{2}$ under-estimation in Turkey probably originates from the understated emissions, which update would resolve the issue. Due to this under-estimation, it is

215 difficult to estimate how conservative the Sunday-level emission reduction is for these holidays (Figure $6 \mathrm{~b}, \mathrm{c})$.

Unlike the Christmas and Easter holidays, which exist in most European countries, especially those with the highest density of the observational network and the strongest emission, the Ramadan Feast days have a substantial effect only for the Turkish stations. At the European scale, the effect is negligible.
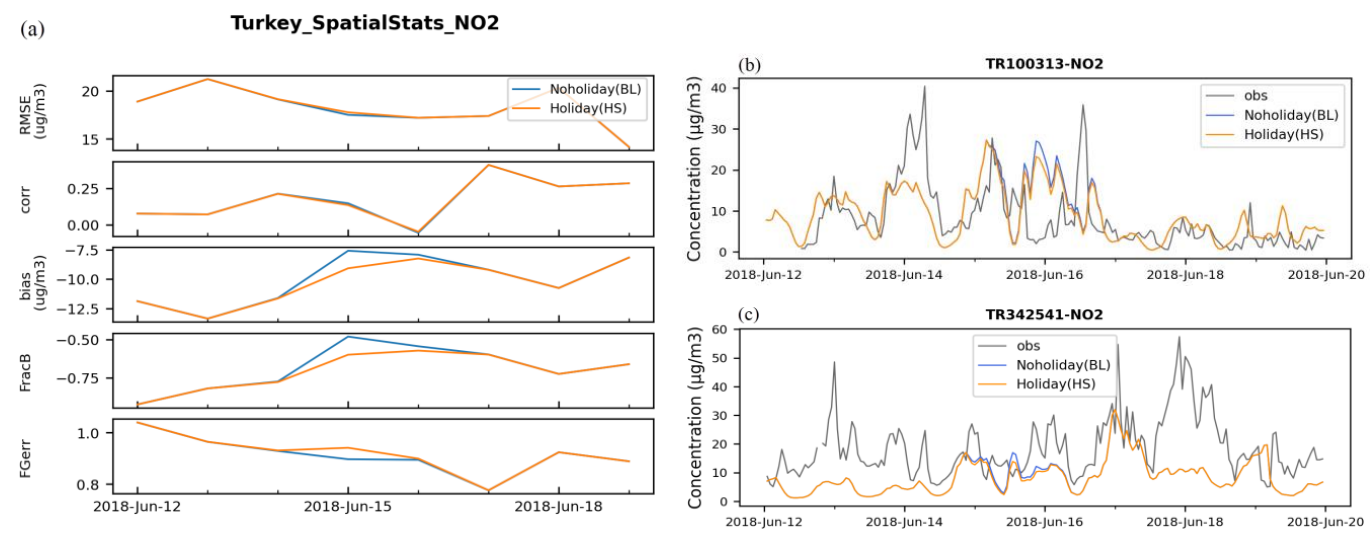

Figure 6. (a): SILAM daily-mean spatial scores for Ramadan (only stations in Turkey), (b, c): Time series of the modelled and observed concentrations for two Turkish stations.

\subsection{Long-term statistics}

At the annual scale, the impacts of holidays on the model performance is limited. The reduction affects only the days with changed emissions and practically do not influence already the next day. The mostsignificant impact was for Christmas and New Year weeks but even for them the effect faded out by the next day. According to the annual statistics, the HS run performed slightly better than the BL: the model bias and RMSE in HS run are lower and correlation is higher than in the BL run. Quantitatively, at annual level the overall effect for $\mathrm{NO}_{2}$ was less than $1 \%$, which reflects the typical number of holiday 
days in a year $(<3 \%)$ and at most $30 \%$ improvement during these days. Impact on other species was lower than that for $\mathrm{NO}_{2}$.

\section{Discussion}

\subsection{Holiday effect on model skills: episodically significant, noticeable at annual level}

The simulations presented in the previous section confirmed that the official holidays substantially affect air quality, as also shown in the studies outlined in the Introduction. The holiday incorporation into the simulations as Sundays, being very simple technically, brings noticeable improvement of the model skills for the days with the modified emission. Since the number of such days in each year is < $3 \%$, the overall improvement of the annual skills is expectedly within $1 \%$, which is quite significant at such level of aggregation.

The suggested simple approach should be considered as only the first step. Holidays are characterised by redistribution of emission due to changing traffic structure, shift of activities from office areas to

240 suburbs, etc. Incorporation of these effects can further improve the model skills but will require quantitative information on such redistribution at the European level. Some support can be found from traffic information, which is presently not available at continental scales.

\subsection{Sunday-based emission reduction for holidays is a conservative estimate}

The simulations also suggested a comparatively simple way to achieve a more significant gain: the

245 Sunday emission scaling (Figure 1) can be amplified. In a few cases, especially for the Christmas and New Year, the actual emission rates might be much lower, whereas for some events the emission of some species might increase. Thus, the New Year night celebration in many countries involves fireworks, which add substantial amount of PM. The second issue is that the Sunday diurnal profile of traffic (also other sources) is substantially different from that of the weekdays. In the present version of

250 SILAM this difference is not accounted for, which evidently limits the model performance and the gain due to the holiday incorporation.

In order to estimate the actual emission reduction over the Christmas and New Year week, we performed a sensitivity simulation HolidayPlus (R3), for which the emission was reduced by $80 \%$ (see Methodology section for details). Being a clear overshot, this run was deemed as the limit-from-below

255 of the emission during the holidays. The corresponding observed and modelled time series of $\mathrm{NO}_{2}$ concentrations at a station in the Netherlands are presented in Figure 7 for the Christmas week. The model scores at the station are generally very good, so we can attribute most of the appearing modelmeasurement discrepancies to the changing emission. As one can see, in the Netherlands the emission starts reducing already one day before the holiday - the $24^{\text {th }}$ of December. The reduction during the $26^{\text {th }}$ 
whereas the $80 \%$ reduction is only slightly too low. Emission is low practically until the $30^{\text {th }}$ of December when it shortly returns to the normal level before the next drop for the New Year celebration. This example shows the challenge of incorporation of such information into the model: formal public holidays tend to influence the emission several days around the event, especially if it appears close to the weekend or another holiday.

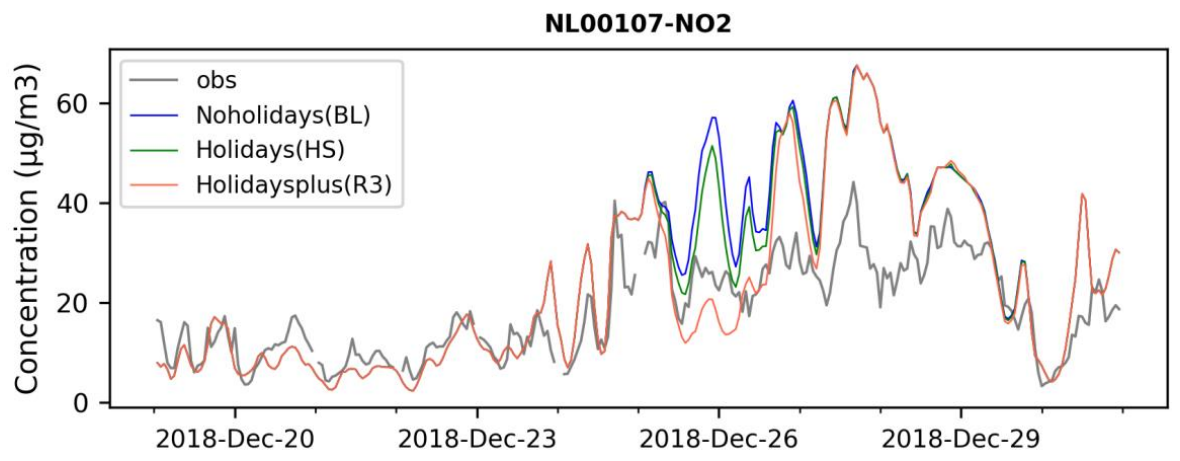

Figure 7. Time series of the modelled (BL and HS runs without and with accounting official holiday, respectively, and Holidaysplus (R3) run with $80 \%$ reduction of emission), and observed concentrations for the selected station.

The present findings are consistent the estimates of observations-based studies. Thus, with Hua et al (2021) also found that the holiday effect is much stronger than the weekend effects. They noticed the opposite signs for $\mathrm{PM}_{2.5}$ and $\mathrm{NO}_{2}$ : average increase of about $22 \%$ and average decrease of about $11 \%$, respectively. Similarly, Retama et al., (2019) reported substantial effect of fireworks on PM at night and the following morning of Christmas Day and the New Year's day. Along the same lines, Rozbicka and Rozbicki (2016), demonstrated that daily mean ozone concentration and maximum ozone peaks are respectively $13 \%$ and $8 \%$ higher than those on weekdays, which also indicates a reduction in NO2 concentrations of about $20 \%$. Conversely, Nodehi et al. (2018) study showed that the Norooz holidays (the Iranian New Year, or a spring festival), are characterised by a reduction of concentration of $\mathrm{PM}_{2.5}$ due to the reduction of the working activities and no massive fireworks. The reported reduction of $\mathrm{PM}_{2.5}$ concentration during the Ramadan Feast holidays is quite close to our estimates.

\subsection{Regional specifics}

The impact of holidays varies from country to country with substantial differences visible even at a subcountry level. The maps of the station-wise temporal correlation coefficients for hourly $\mathrm{NO}_{2}, \mathrm{CO}, \mathrm{O}_{3}$, and $\mathrm{PM}_{2.5}$ concentrations (Figure 8, Figure 9) reveal a strong inhomogeneity of the effect for Christmas and New Year weeks. The effect can dramatically vary even within a single country - as seen from the comparison of maps of Figure 8 and country-median correlation coefficient of Figure 9. 
In the case of $\mathrm{NO}_{2}$, correlation increases, e.g., in Northern Germany, Italy, Poland and Eastern part of Finland for both HS and R3 runs. Conversely, there was no effect or even deterioration of skills in Southern Germany, Northern France, Madrid region, etc. Other species showed qualitatively similar patterns but lower gains and losses. Surprisingly, skills over most of France are generally worse for the HS run and much worse for R3 indicating a substantially different pattern of activities during holidays, compared to those of the neighboring countries. The R3 run, which was planned as an overshot, showed strong improvement of temporal correlation in Eastern Europe, Central and Northern Italy and Northern Germany. Therefore, one can argue that the 5-fold- emission reduction in these countries / regions might be not that much of an exaggeration. The issue deserves a more detailed analysis accounting for 295 the varying traffic patterns and effects on days preceding to and following the official holidays. 
BL: Corr NO2, all stations

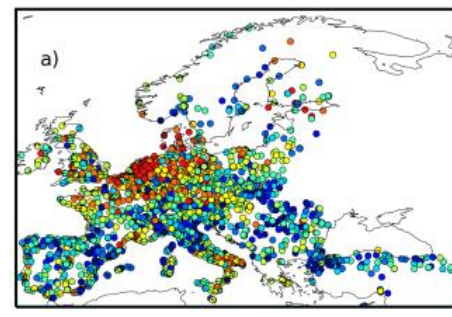

BL: Corr $\mathrm{CO}$, all stations

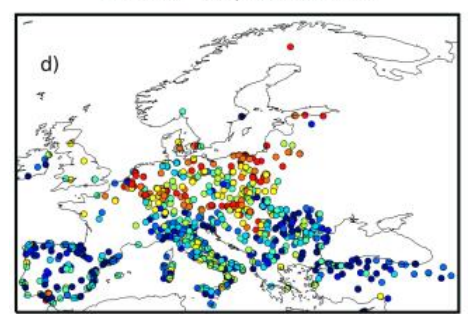

BL: Corr O3, all stations

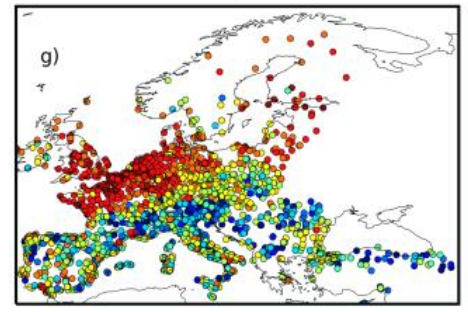

BL: Corr PM25, all stations
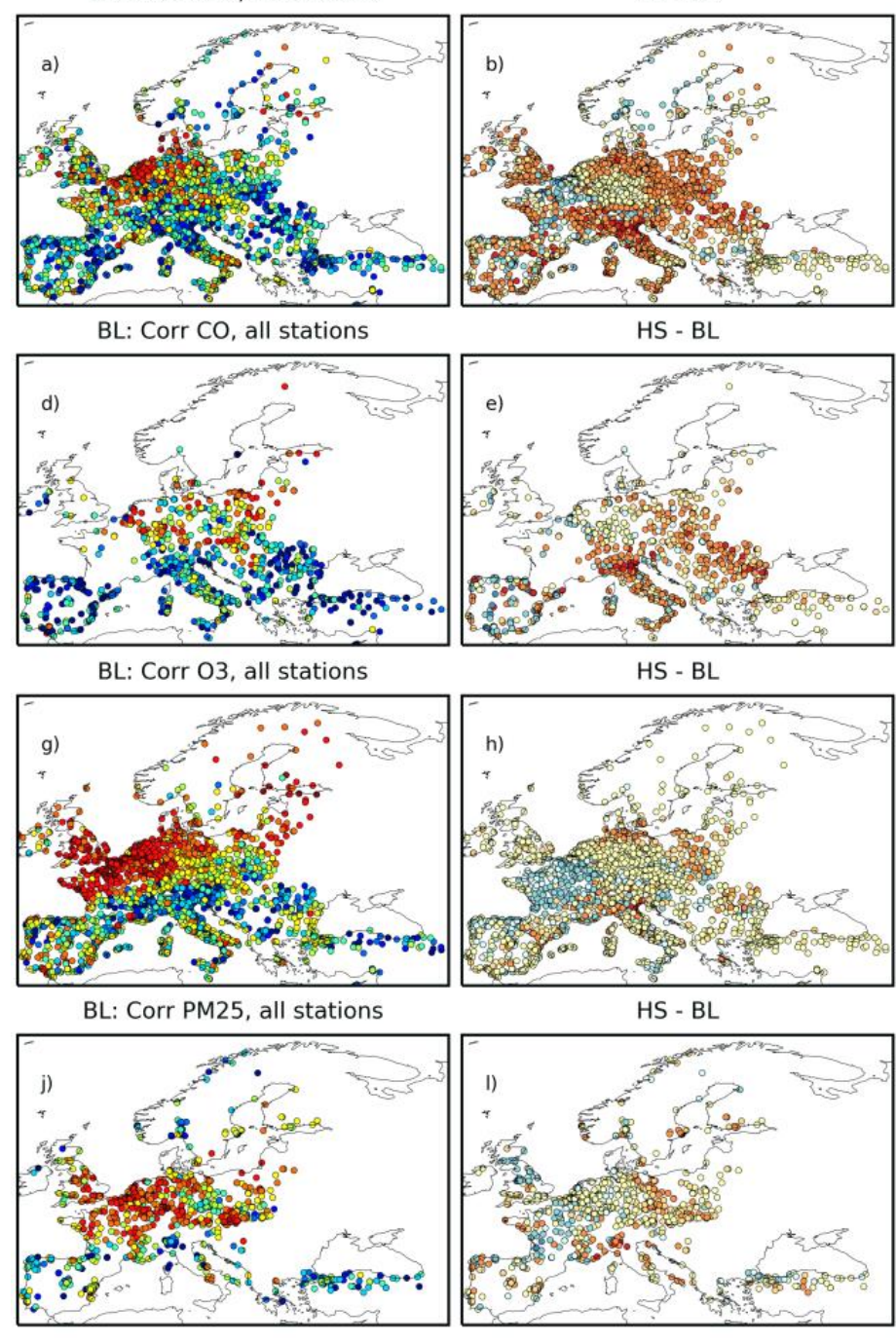

HS - BL
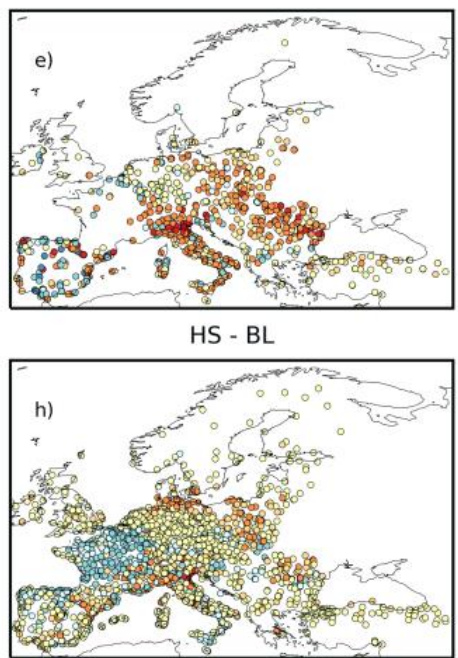

$\begin{array}{lllllllll}0.1 & 0.2 & 0.3 & 0.4 & 0.5 & 0.6 & 0.7 & 0.8 & 0.9\end{array}$
HS - BL

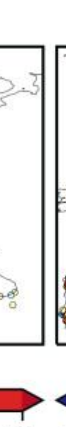

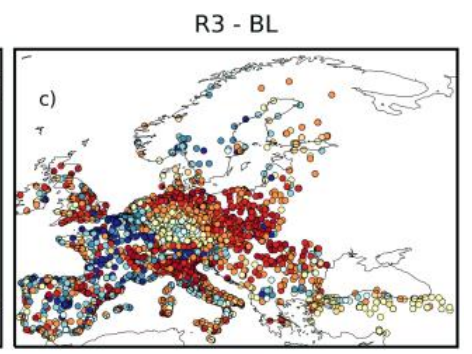

R3 - BL

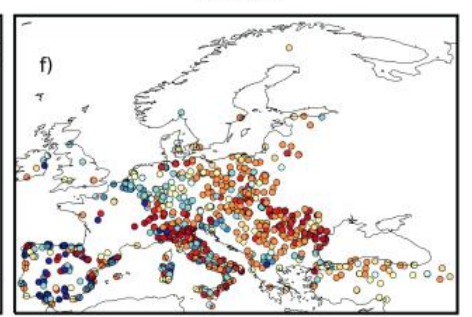

R3 - BL

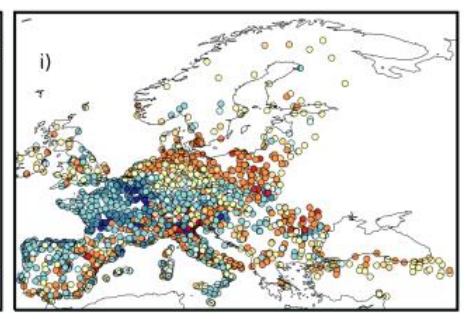

R3 - BL
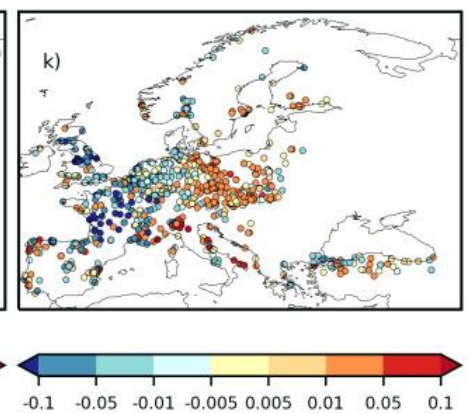

Figure 8. Maps of the temporal correlation coefficient of hourly $\mathrm{NO}_{2}, \mathrm{CO}, \mathrm{O}_{3}$, and $\mathrm{PM}_{2.5}$ concentrations for the EEA stations during the Christmas holidays (21-31 December 2018). 

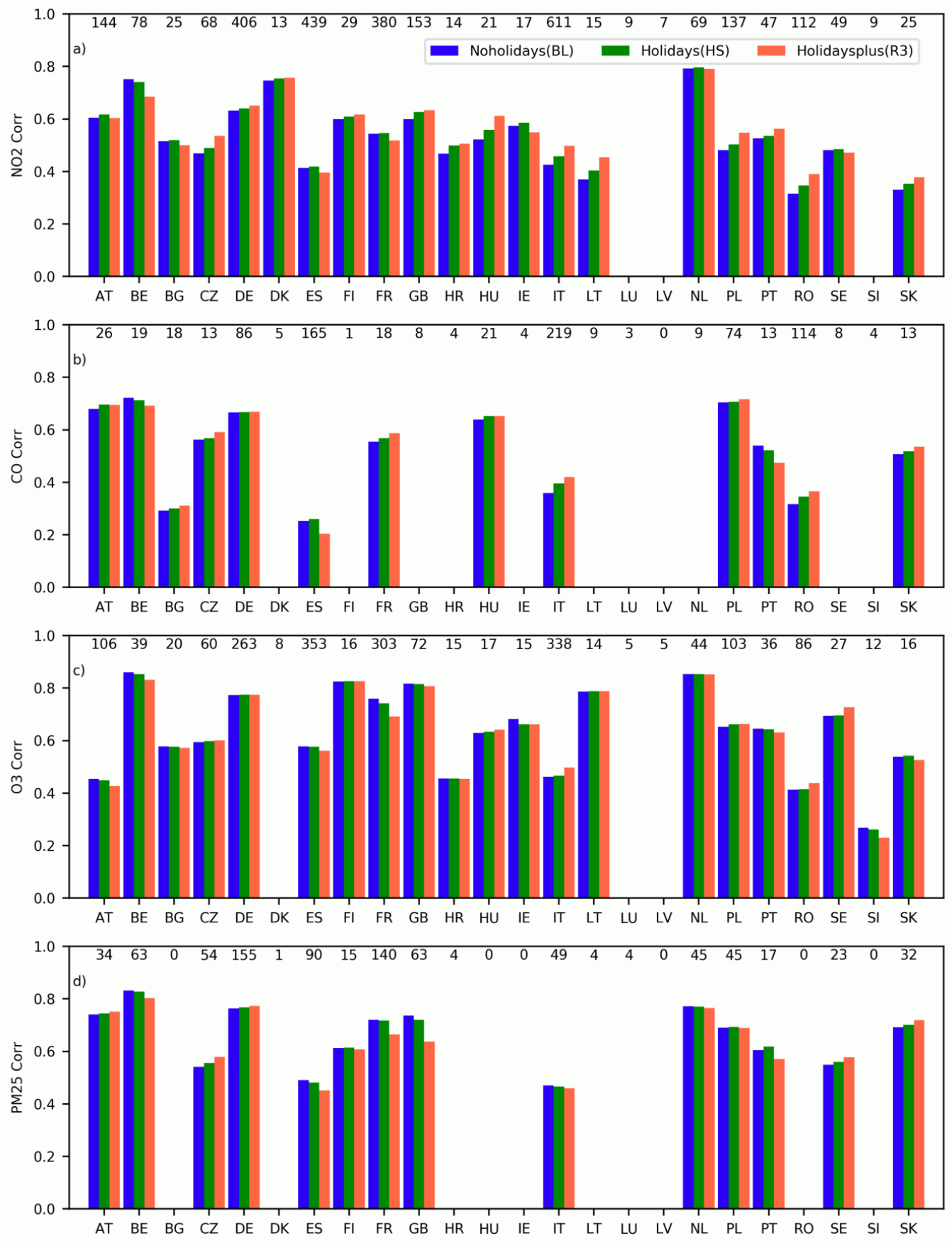

Figure 9. Country-wise median change of temporal correlation coefficient during two weeks of Christmas holidays (21-31 December 2018). The numbers at the top of each panel shows the number of stations that reported data for the period. 


\section{Summary}

Incorporation of information on public holidays in emission of the affected anthropogenic sectors leads to substantial short-term improvements of the SILAM model scores, even if done conservatively. The largest impact was found for NOx, which is controlled by the changes of the traffic intensity. Certain improvements were also found for $\mathrm{PM}_{2.5}$ and ozone but the signal was weaker than that for NOx.

The effect of the emission reduction during holidays may look detrimental in case of a systematic under-estimation in some regions. However, in majority of such cases the bias became more homogeneous in time and thus easier to handle with, e.g., emission corrections via data assimilation or development of new emission inventories.

315 The sensitivity runs confirmed that the Sunday emission level, in many cases, is a too conservative proxy for the public-holiday emission. Thus, the reduction during Christmas and New Year holidays of 2018 was closer to a factor of 4 in Western Europe and possibly even stronger in Eastern Europe.

The current experiment used the prescribed sector-specific diurnal profiles of emission intensity, same for weekdays, weekends and holidays. Incorporation of specific profiles for weekends and holidays, when they become available, will further improve the quality of the model predictions.

The proposed method of handling emission reduction in AQ models, albeit very simple and with a room for improvement, gives noticeable gains in the model performance scores. The method is straightforward to implement in AQ models and can be considered as an easy way to significantly improve the model prediction skills for the periods of public holidays. An in-depth analysis of the

325 specific holidays and related traditions in specific countries, such as fireworks in New Year night, would, most probably, lead to further improvements of the AQ predictions.

\section{Code and data availability}

SILAM is an open-code system and can be obtained from the GitHub open repository (https://github.com/fmidev/silam-model, Kouznetsov and Delgado, 2021). The simulation results are available on request from the authors of the paper.

\section{Author contribution}

The authors jointly devised the project and developed the paper concept. YF contributed to the implementation of the research and analysis of the results, and drafted the paper. RK performed the

335 SILAM computations and contributed to the analysis. MS contributed to the analysis, drafted the Discussion and contributed to other sections of the paper. All authors edited the final text. 


\section{Acknowledgements}

The study was performed within the scope of Academy of Finland project GLORIA (grant Nbr 310372). Financial support of Copernicus Atmospheric Monitoring Service (CAMS-50 and CAMS-61) for the SILAM development is kindly acknowledged.

\section{References}

Beirle, S., Platt, U., Wenig, M., and Wagner, T.: Weekly cycle of NO2 by GOME measurements: a signature of anthropogenic sources, 8, 2003.

Brasseur, G. P., Xie, Y., Petersen, A. K., Bouarar, I., Flemming, J., Gauss, M., Jiang, F., Kouznetsov,

345 R., Kranenburg, R., Mijling, B., Peuch, V.-H., Pommier, M., Segers, A., Sofiev, M., Timmermans, R., van der A, R., Walters, S., Xu, J., and Zhou, G.: Ensemble forecasts of air quality in eastern China Part 1: Model description and implementation of the MarcoPolo-Panda prediction system, version 1, 12, 33-67, https://doi.org/10.5194/gmd-12-33-2019, 2019.

Carslaw, K. S., Luo, B., and Peter, T.: An analytic expression for the composition of aqueous $\mathrm{HNO}_{3}-\mathrm{H}$

$350{ }_{2} \mathrm{SO}_{4}$ stratospheric aerosols including gas phase removal of $\mathrm{HNO}_{3}$, Geophys. Res. Lett., 22, 18771880, https://doi.org/10.1029/95GL01668, 1995.

Chen, P.-Y., Tan, P.-H., Chou, C. C.-K., Lin, Y.-S., Chen, W.-N., and Shiu, C.-J.: Impacts of holiday characteristics and number of vacation days on "holiday effect" in Taipei: Implications on ozone control strategies, Atmospheric Environment, 202, 357-369, https://doi.org/10.1016/j.atmosenv.2019.01.029,

3552019.

Damski, J., Thölix, L., Backman, L., Taalas, P., and Kulmala, M.: FinROSE — middle atmospheric chemistry transport model, 12, 535-550, 2007.

Dasari, H. P., Desamsetti, S., Langodan, S., Karumuri, R. K., Singh, S., and Hoteit, I.: Atmospheric conditions and air quality assessment over NEOM, kingdom of Saudi Arabia, Atmospheric Environment, 230, 117489, https://doi.org/10.1016/j.atmosenv.2020.117489, 2020.

Derwent, R. and Hjellbrekke, A.-Gunn.: Air Pollution by Ozone Across Europe: Handbook of Environmental Chemistry, Springer, Berlin, Heidelberg, 371 pp., 2012.

Ding, J., Miyazaki, K., Cho, S., Janssens-Maenhout, G., Zhang, Q., Liu, F., and Levelt, P. F.: Intercomparison of NOx emission inventories over East Asia, 17, 2017.

365 Elansky, N. F.: Weekly patterns and weekend effects of air pollution in the Moscow megacity, 15, 2020 .

European Environment Agency:: EMEP/EEA air pollutant emission inventory guidebook 2013: technical guidance to prepare national emission inventories., Publications Office, LU, 2013.

Fan, C., Li, Z., Li, Y., Dong, J., van der A, R., and de Leeuw, G.: Does reduction of emissions imply

370 improved air quality?, Gases/Remote Sensing/Troposphere/Chemistry (chemical composition and reactions), https://doi.org/10.5194/acp-2020-1101, 2020.

Forster, P. M. de F. and Solomon, S.: Observations of a "Weekend Effect" in Diurnal Temperature Range, 100, 11225-11230, 2003. 
de Foy, B., Lu, Z., and Streets, D. G.: Impacts of control strategies, the Great Recession and weekday variations on NO 2 columns above North American cities, Atmospheric Environment, 138, 74-86, https://doi.org/10.1016/j.atmosenv.2016.04.038, 2016.

de Foy, B., Brune, W. H., and Schauer, J. J.: Changes in ozone photochemical regime in Fresno, California from 1994 to 2018 deduced from changes in the weekend effect, Environmental Pollution, 263, 114380, https://doi.org/10.1016/j.envpol.2020.114380, 2020.

380 Frost, G. J., Middleton, P., Tarrasón, L., Granier, C., Guenther, A., Cardenas, B., Denier van der Gon, H., Janssens-Maenhout, G., Kaiser, J. W., Keating, T., Klimont, Z., Lamarque, J.-F., Liousse, C., Nickovic, S., Ohara, T., Schultz, M. G., Skiba, U., van Aardenne, J., and Wang, Y.: New Directions: GEIA's 2020 vision for better air emissions information, Atmospheric Environment, 81, 710-712, https://doi.org/10.1016/j.atmosenv.2013.08.063, 2013.

385 Fu, D., Song, Z., Zhang, X., Wu, Y., Duan, M., Pu, W., Ma, Z., Quan, W., Zhou, H., Che, H., and Xia, X.: Similarities and Differences in the Temporal Variability of PM2.5 and AOD Between Urban and Rural Stations in Beijing, Remote Sensing, 12, 1193, https://doi.org/10.3390/rs12071193, 2020.

Fu, X., Wang, S., Zhao, B., Xing, J., Cheng, Z., Liu, H., and Hao, J.: Emission inventory of primary pollutants and chemical speciation in 2010 for the Yangtze River Delta region, China, Atmospheric Environment, 70, 39-50, https://doi.org/10.1016/j.atmosenv.2012.12.034, 2013.

Galperin, M. V., Maslyaev, A. M., Pekar, M. I., and Sofiev, M.: The development of HM model in 1996, Meteorological Synthesising Centre East, Moscow, 1996.

Gery, M. W., Whitten, G. Z., Killus, J. P., and Dodge, M. C.: A photochemical kinetics mechanism for urban and regional scale computer modelling, 94, 12925-12956, https://doi.org/0148-0227/89/89JD-

$39500793 \$ 05.00,1989$.

Gioli, B., Gualtieri, G., Busillo, C., Calastrini, F., Zaldei, A., and Toscano, P.: Improving high resolution emission inventories with local proxies and urban eddy covariance flux measurements, Atmospheric Environment, 115, 246-256, https://doi.org/10.1016/j.atmosenv.2015.05.068, 2015.

Gour, A. A., Singh, S. K., Tyagi, S. K., and Mandal, A.: Weekday/weekend differences in air quality parameters in delhi, india, 1, 69-76, 2013.

Granier, C., Bessagnet, B., Bond, T., D’Angiola, A., Denier van der Gon, H., Frost, G. J., Heil, A., Kaiser, J. W., Kinne, S., Klimont, Z., Kloster, S., Lamarque, J.-F., Liousse, C., Masui, T., Meleux, F., Mieville, A., Ohara, T., Raut, J.-C., Riahi, K., Schultz, M. G., Smith, S. J., Thompson, A., van Aardenne, J., van der Werf, G. R., and van Vuuren, D. P.: Evolution of anthropogenic and biomass

405 burning emissions of air pollutants at global and regional scales during the 1980-2010 period, Climatic Change, 109, 163-190, https://doi.org/10.1007/s10584-011-0154-1, 2011.

Granier, C., Darras, S., Denier van der Gon, H., Doubalova, J., Elguindi, N., Galle, B., Gauss, M., Guevara, M., Jalkanen, J.-P., Kuenen, J., Liousse, C., Quack, B., Simpson, D., and Sindelarova, K.: The Copernicus Atmosphere Monitoring Service global and regional emissions (April 2019 version), https://doi.org/10.24380/D0BN-KX16, 2019.

Grivas, G., Athanasopoulou, E., Kakouri, A., Bailey, J., Liakakou, E., Stavroulas, I., Kalkavouras, P., Bougiatioti, A., Kaskaoutis, D. G., Ramonet, M., Mihalopoulos, N., and Gerasopoulos, E.: Integrating In Situ Measurements and City Scale Modelling to Assess the COVID-19 Lockdown Effects on Emissions and Air Quality in Athens, Greece, 21, 2020. 
415 Guevara, M., Lopez-Aparicio, S., Cuvelier, C., Tarrason, L., Clappier, A., and Thunis, P.: A benchmarking tool to screen and compare bottom-up and top-down atmospheric emission inventories, Air Qual Atmos Health, 10, 627-642, https://doi.org/10.1007/s11869-016-0456-6, 2017.

Guevara, M., Jorba, O., Tena, C., Denier van der Gon, H., Kuenen, J., Elguindi, N., Darras, S., Granier, C., and Pérez García-Pando, C.: Copernicus Atmosphere Monitoring Service TEMPOral profiles

420 (CAMS-TEMPO): global and European emission temporal profile maps for atmospheric chemistry modelling, Earth Syst. Sci. Data, 13, 367-404, https://doi.org/10.5194/essd-13-367-2021, 2021.

Hassan, S. K., El-Abssawy, A. A., AbdEl-Maksoud, A. S., Abdou, M. H., and Khoder, M. I.: Seasonal Behaviours and Weekdays/Weekends Differences in Elemental Composition of Atmospheric Aerosols in Cairo, Egypt, Aerosol Air Qual. Res., 13, 1552-1562, https://doi.org/10.4209/aaqr.2012.12.0349, 2013.

Hoyos, C. D., Herrera-Mejía, L., Roldán-Henao, N., and Isaza, A.: Effects of fireworks on particulate matter concentration in a narrow valley: the case of the Medellín metropolitan area, Environ Monit Assess, 192, 6, https://doi.org/10.1007/s10661-019-7838-9, 2020.

Hua, J., Zhang, Y., de Foy, B., Mei, X., Shang, J., and Feng, C.: Competing PM2.5 and NO2 holiday 430 effects in the Beijing area vary locally due to differences in residential coal burning and traffic patterns, Science of The Total Environment, 750, 141575, https://doi.org/10.1016/j.scitotenv.2020.141575, 2021.

Huang, X., Ding, A., Gao, J., Zheng, B., Zhou, D., Qi, X., Tang, R., Wang, J., Ren, C., Nie, W., Chi, X., Xu, Z., Chen, L., Li, Y., Che, F., Pang, N., Wang, H., Tong, D., Qin, W., Cheng, W., Liu, W., Fu, Q., Liu, B., Chai, F., Davis, S. J., Zhang, Q., and He, K.: Enhanced secondary pollution offset reduction of

435 primary emissions during COVID-19 lockdown in China, 10, https://doi.org/10.1093/nsr/nwaa137, 2020 .

Iriti, M., Piscitelli, P., Missoni, E., and Miani, A.: Air Pollution and Health: The Need for a Medical Reading of Environmental Monitoring Data, IJERPH, 17, 2174, https://doi.org/10.3390/ijerph17072174, 2020.

440 Jacob, D. J. and Winner, D. A.: Effect of climate change on air quality, 43, 51-63, https://doi.org/10.1016/j.atmosenv.2008.09.051, 2009.

Jhun, I., Coull, B. A., Schwartz, J., Hubbell, B., and Koutrakis, P.: The impact of weather changes on air quality and health in the United States in 1994-2012, Environ. Res. Lett., 10, 084009, https://doi.org/10.1088/1748-9326/10/8/084009, 2015.

445 Jiang, Q., Sun, Y. L., Wang, Z., and Yin, Y.: Aerosol composition and sources during the Chinese Spring Festival: fireworks, secondary aerosol, and holiday effects, Atmos. Chem. Phys., 15, 6023-6034, https://doi.org/10.5194/acp-15-6023-2015, 2015.

Joly, M. and Peuch, V.-H.: Objective classification of air quality monitoring sites over Europe, Atmospheric Environment, 47, 111-123, https://doi.org/10.1016/j.atmosenv.2011.11.025, 2012.

450 Karl, M., Bieser, J., Geyer, B., Matthias, V., Jalkanen, J.-P., Johansson, L., and Fridell, E.: Impact of a nitrogen emission control area (NECA) on the future air quality and nitrogen deposition to seawater in the Baltic Sea region, Atmos. Chem. Phys., 19, 1721-1752, https://doi.org/10.5194/acp-19-1721-2019, 2019.

Khalil, M. A. K., Butenhoff, C. L., Porter, W. C., Almazroui, M., Alkhalaf, A., and Al-Sahafi, M. S.: 455 Air quality in Yanbu, Saudi Arabia, Journal of the Air \& Waste Management Association, 66, 341-355, https://doi.org/10.1080/10962247.2015.1129999, 2016. 
Khezri, B., Chan, Y. Y., Tiong, L. Y. D., and Webster, R. D.: Annual air pollution caused by the Hungry Ghost Festival, Environ. Sci.: Processes Impacts, 17, 1578-1586, https://doi.org/10.1039/C5EM00312A, 2015.

460 Kouznetsov, R. and Delgado, R.: SILAM open code at GitHub, available at: https://github.com/fmidev/silam-model, last access: 23 February 2021.

Kouznetsov, R. and Sofiev, M.: A methodology for evaluation of vertical dispersion and dry deposition of atmospheric aerosols, 117, https://doi.org/doi:10.1029/2011JD016366, 2012.

Kouznetsov, R., Sofiev, M., Vira, J., and Stiller, G.: Simulating age of air and the distribution of

465 SF\&lt;sub\&gt;6\&lt;/sub\&gt; in the stratosphere with the SILAM model, Atmos. Chem. Phys., 20, 5837-5859, https://doi.org/10.5194/acp-20-5837-2020, 2020.

Kukkonen, J., López-Aparicio, S., Segersson, D., Geels, C., Kangas, L., Kauhaniemi, M., Maragkidou, A., Jensen, A., Assmuth, T., Karppinen, A., Sofiev, M., Hellén, H., Riikonen, K., Nikmo, J., Kousa, A., Niemi, J. V., Karvosenoja, N., Santos, G. S., Sundvor, I., Im, U., Christensen, J. H., Nielsen, O.-K.,

470 Plejdrup, M. S., Nøjgaard, J. K., Omstedt, G., Andersson, C., Forsberg, B., and Brandt, J.: The influence of residential wood combustion on the concentrations of PM\&lt;sub\&gt;2.5\&lt;/sub\&gt; in four Nordic cities, Atmos. Chem. Phys., 20, 4333-4365, https://doi.org/10.5194/acp-20-4333-2020, 2020.

Lai, Y. and Brimblecombe, P.: Regulatory effects on particulate pollution in the early hours of Chinese New Year, 2015, Environ Monit Assess, 189, 467, https://doi.org/10.1007/s10661-017-6167-0, 2017.

475 Lehtomäki, H., Korhonen, A., Asikainen, A., Karvosenoja, N., Kupiainen, K., Paunu, V.-V., Savolahti, M., Sofiev, M., Palamarchuk, Y., Karppinen, A., Kukkonen, J., and Hänninen, O.: Health impacts of ambient air pollution in Finland, 15, https://doi.org/10.3390/ijerph15040736, 2018.

Lonati, G., Giugliano, M., and Cernuschi, S.: The role of traffic emissions from weekends' and weekdays' fine PM data in Milan, Atmospheric Environment, 40, 5998-6011, https://doi.org/10.1016/j.atmosenv.2005.12.033, 2006.

McGraw, J., Haas, P., Young, L., and Evens, A.: Greenhouse gas emissions in Chicago: Emissions inventories and reduction strategies for Chicago and its metropolitan region, Journal of Great Lakes Research, 36, 106-114, https://doi.org/10.1016/j.jglr.2009.11.010, 2010.

Menut, L., Bessagnet, B., Siour, G., Mailler, S., Pennel, R., and Cholakian, A.: Impact of lockdown 485 measures to combat Covid-19 on air quality over western Europe, 741, 140426-140426, https://doi.org/10.1016/j.scitotenv.2020.140426, 2020.

Nodehi, R. N., Hashemi, S. Y., and Azimi, F.: The effect of national events and holidays on ambi- ent pm2.5 concentrations, 3, 109-118, 2018.

Parra, R. and Franco, E.: Identifying the Ozone Weekend Effect in the air quality of the northern Andean region of Ecuador, 207, 12, 2016.

Petersen, A. K., Brasseur, G. P., Bouarar, I., Flemming, J., Gauss, M., Jiang, F., Kouznetsov, R., Kranenburg, R., Mijling, B., Peuch, V.-H., Pommier, M., Segers, A., Sofiev, M., Timmermans, R., van $\operatorname{der}$ A, R., Walters, S., Xie, Y., Xu, J., and Zhou, G.: Ensemble forecasts of air quality in eastern China - Part 2: Evaluation of the MarcoPolo-Panda prediction system, version 1, 12, 1241-1266, 495 https://doi.org/10.5194/gmd-12-1241-2019, 2019.

Poupkou, A., Giannaros, T., Markakis, K., Kioutsioukis, I., Curci, G., Melas, D., and Zerefos, C.: A model for European Biogenic Volatile Organic Compound emissions: Software development and first 
validation, Environmental Modelling \& Software, 25, 1845-1856, https://doi.org/10.1016/j.envsoft.2010.05.004, 2010.

500 Retama, A., Neria-Hernández, A., Jaimes-Palomera, M., Rivera-Hernández, O., Sánchez-Rodríguez, M., López-Medina, A., and Velasco, E.: Fireworks: A major source of inorganic and organic aerosols during Christmas and New Year in Mexico city, Atmospheric Environment: X, 2, 100013, https://doi.org/10.1016/j.aeaoa.2019.100013, 2019.

Rozbicka, K. and Rozbicki, T.: The "Weekend Effect" on Ozone in the Warsaw Conurbation, Poland,

505 Pol. J. Environ. Stud., 25, 1675-1683, https://doi.org/10.15244/pjoes/61815, 2016.

Sharma, S., Zhang, M., Anshika, Gao, J., Zhang, H., and Kota, S. H.: Effect of restricted emissions during COVID-19 on air quality in India, Science of The Total Environment, 728, 138878, https://doi.org/10.1016/j.scitotenv.2020.138878, 2020.

Shi, C., Wu, H., and Chiu, Y.-H.: The Dynamic Analysis of the Pollutant Emissions Impact on Human

510 Health in China Industries Based on the Meta-Frontier DEA, Healthcare, 8, 5, https://doi.org/10.3390/healthcare8010005, 2019.

Singh, A., Pant, P., and Pope, F. D.: Air quality during and after festivals: Aerosol concentrations, composition and health effects, 227, 220-232, https://doi.org/10.1016/j.atmosres.2019.05.012, 2019.

Singh, K. P., Gupta, S., and Rai, P.: Identifying pollution sources and predicting urban air quality using

515 ensemble learning methods, Atmospheric Environment, 80, 426-437, https://doi.org/10.1016/j.atmosenv.2013.08.023, 2013.

Sofiev, M.: A model for the evaluation of long-term airborne pollution transport at regional and continental scales, 34, 2481-2493, 2000.

Sofiev, M.: Extended resistance analogy for construction of the vertical diffusion scheme for dispersion models, 107, ACH 10-1-ACH 10-8, https://doi.org/10.1029/2001JD001233, 2002.

Sofiev, M.: On possibilities of assimilation of near-real-time pollen data by atmospheric composition models, 1, https://doi.org/10.1007/s10453-019-09583-1, 2019.

Sofiev, M., Siljamo, P., Valkama, I., Ilvonen, M., and Kukkonen, J.: A dispersion modelling system SILAM and its evaluation against ETEX data, 40, 674-685,

525 https://doi.org/10.1016/j.atmosenv.2005.09.069, 2006.

Sofiev, M., Genikhovich, E., Keronen, P., and Vesala, T.: Diagnosing the Surface Layer Parameters for Dispersion Models within the Meteorological-to-Dispersion Modeling Interface, 49, 221-233, https://doi.org/10.1175/2009JAMC2210.1, 2010.

Sofiev, M., Soares, J., Prank, M., de Leeuw, G., and Kukkonen, J.: A regional-to-global model of

530 emission and transport of sea salt particles in the atmosphere, 116, https://doi.org/10.1029/2010JD014713, 2011.

Sofiev, M., Vira, J., Kouznetsov, R., Prank, M., Soares, J., and Genikhovich, E.: Construction of an Eulerian atmospheric dispersion model based on the advection algorithm of M. Galperin: dynamic cores v.4 and 5 of SILAM v.5.5, 8, 3497-3522, https://doi.org/10.5194/gmd-8-3497-2015, $2015 \mathrm{a}$.

535 Sofiev, M., Berger, U., Prank, M., Vira, J., Arteta, J., Belmonte, J., Bergmann, K. C., Charoux, F., Elbern, H., Friese, E., Galan, C., Gehrig, R., Khvorostyanov, D., Kranenburg, R., Kumar, U., Marecal, V., Meleux, F., Menut, L., Pessi, A.-M., Robertson, L., Ritenberga, O., Rodinkova, V., Saarto, A., Segers, A., Severova, E., Sauliene, I., Siljamo, P., Steensen, B. M., Teinemaa, E., Thibaudon, M., and 
Peuch, V.-H.: MACC regional multi-model ensemble simulations of birch pollen dispersion in Europe, 15, 8115-8130, https://doi.org/10.5194/acp-15-8115-2015, 2015b.

Sofiev, M., Kouznetsov, R., Hänninen, R., and Sofieva, V. F.: Technical note: Intermittent reduction of the stratospheric ozone over northern Europe caused by a storm in the Atlantic Ocean, Atmos. Chem. Phys., 20, 1839-1847, https://doi.org/10.5194/acp-20-1839-2020, 2020.

Vira, J. and Sofiev, M.: On variational data assimilation for estimating the model initial conditions and

545 emission fluxes for short-term forecasting of SOx concentrations, 46, 318-328, https://doi.org/10.1016/j.atmosenv.2011.09.066, 2012.

Wang, Q. and Su, M.: A preliminary assessment of the impact of COVID-19 on environment - A case study of China, Science of The Total Environment, 728, 138915, https://doi.org/10.1016/j.scitotenv.2020.138915, 2020.

550 Wesely, M. L.: Parameterization of surface resistances to gaseous dry deposition in regional-scale numerical models, 23, 1293-1304, 1989.

Xian, P., Reid, J. S., Hyer, E. J., Sampson, C. R., Rubin, J. I., Ades, M., Asencio, N., Basart, S., Benedetti, A., Bhattacharjee, P. S., Brooks, M. E., Colarco, P. R., da Silva, A. M., Eck, T. F., Guth, J., Jorba, O., Kouznetsov, R., Kipling, Z., Sofiev, M., Perez Garcia-Pando, C., Pradhan, Y., Tanaka, T.,

555 Wang, J., Westphal, D. L., Yumimoto, K., and Zhang, J.: Current state of the global operational aerosol multi-model ensemble: An update from the International Cooperative for Aerosol Prediction (ICAP), 145, 176-209, https://doi.org/10.1002/qj.3497, 2019.

Xu, Z., Huang, X., Nie, W., Chi, X., Xu, Z., Zheng, L., Sun, P., and Ding, A.: Influence of synoptic condition and holiday effects on VOCs and ozone production in the Yangtze River Delta region, China,

560 Atmospheric Environment, 168, 112-124, https://doi.org/10.1016/j.atmosenv.2017.08.035, 2017.

Yao, L., Wang, D., Fu, Q., Qiao, L., Wang, H., Li, L., Sun, W., Li, Q., Wang, L., Yang, X., Zhao, Z., Kan, H., Xian, A., Wang, G., Xiao, H., and Chen, J.: The effects of firework regulation on air quality and public health during the Chinese Spring Festival from 2013 to 2017 in a Chinese megacity, Environment International, 126, 96-106, https://doi.org/10.1016/j.envint.2019.01.037, 2019.

565 Yarwood, G., Rao, S., Yocke, M., and Whitten, G. Z.: Updates to the carbon bond chemical mechanism: CB05, US EPA, 2005.

Ye, C., Chen, R., and Chen, M.: The impacts of Chinese Nian culture on air pollution, Journal of Cleaner Production, 112, 1740-1745, https://doi.org/10.1016/j.jclepro.2015.04.113, 2016.

Zhao, Y., Qiu, L. P., Xu, R. Y., Xie, F. J., Zhang, Q., Yu, Y. Y., Nielsen, C. P., Qin, H. X., Wang, H.

570 K., Wu, X. C., Li, W. Q., and Zhang, J.: Advantages of a city-scale emission inventory for urban air quality research and policy: the case of Nanjing, a typical industrial city in the Yangtze River Delta, China, Atmos. Chem. Phys., 15, 12623-12644, https://doi.org/10.5194/acp-15-12623-2015, 2015.

Zhou, M., Jiang, W., Gao, W., Zhou, B., and Liao, X.: A high spatiotemporal resolution anthropogenic VOC emission inventory for Qingdao City in 2016 and its ozone formation potential analysis, Process

575 Safety and Environmental Protection, 139, 147-160, https://doi.org/10.1016/j.psep.2020.03.040, 2020.

Zou, Y., Charlesworth, E., Yin, C. Q., Yan, X. L., Deng, X. J., and Li, F.: The weekday/weekend ozone differences induced by the emissions change during summer and autumn in Guangzhou, China, Atmospheric Environment, 199, 114-126, https://doi.org/10.1016/j.atmosenv.2018.11.019, 2019. 